\title{
KOMPETENSI SDM KEUANGAN DAN AKUNTABILITAS PESANTREN
}

\author{
Yunika Murdayanti and Dita Puruwita \\ Fakultas Ekonomi \\ Universitas Negeri Jakarta \\ Jl Rawamangun Muka No.1 Jakarta Timur 13220 \\ Email: yunika_murdayanti@unj.ac.id
}

\begin{abstract}
Abstrak
Pengelolaan keuangan di Pesantren sebenarnya tidak begitu rumit, sebab pesantren merupakan lembaga swaDana yang tidak memerlukan pertanggungjawaban keuangan yang terlalu pelik kepada penyandang Dananya. Penelitian ini membahas kompetensi SDM keuangan dalam akuntabilitas di lingkungan Pesantren (Lembaga Pendidikan Islam). Observasi dilakukan peneliti terhadap pengelolaan keuangan di 6 Pondok Pesantren Jabodetabek. Populasinya adalah seluruh pegawai yang berada di pesantren. Teknik pengambilan sampel menggunakan metode purposive sampling dengan total responden yang diperoleh sebesar 116 responden. Dari penelitian ini, metode analisis data yang digunakan adalah analisis regresi. Kesimpulan penelitian menunjukkan bahwa kompetensi SDM keuangan berpengaruh positif terhadap akuntabilitas. Artinya SDM yang kompeten mampu memahami logika akuntansi dengan baik. Semakin tinggi SDM keuangan maka akan berpengaruh pada penerapan akuntabilitas pesantren secara baik dan memadai.
\end{abstract}

Kata Kunci: Kompetensi SDM Keuangan, Akuntabilitas, Pesantren (Lembaga Pendidikan Islam)

\begin{abstract}
Financial management of pesantren is not so complicated, because pesantren are self-financing institutions that do not require financial accountability to be reported to the funder. Generally, this study discusses about the competence of financial human resources against accountability in the environment of Pesantren (Islamic Education Institution). Observations conducted by researchers on financial management in 6 Pesantren at Jabodetabek. Its population is all employees who are in pesantren. The sample was selected using purposive sampling amounted to 116 respondents. The data analysis method uses regression testing. Conclusion of this study proves that the competence of financial human resources have a positive and significant impact on accountability. The higher of the financial human resources will have an effect on the implementation of accountability at pesantren well and adequate.
\end{abstract}

Keywords: Financial Human Resources Competency, Accountability, Pesantren (Islamic Education Institution)

\section{Pendahuluan}

Pesantren telah memberikan tanggapan positif terhadap pembangunan nasional dalam bidang pendidikan. Dengan didirikannya sekolah-sekolah umum maupun madrasah-madrasah di lingkungan pesantren membuat pesantren kaya diverifikasi lembaga pendidikan dan peningkatan institusional pondok pesantren dalam kerangka pendidikan nasional. Pemerintah memberikan wewenang penuh kepada Departemen Agama (Kementerian Agama) Republik Indonesia untuk mengatur penyelenggaraan pendidikan di Madrasah dan Pondok Pesantren, baik dalam hal pembiayaan, pengadaan dan pengembangan sumberdaya manusia. Pengembangan kelembagaan dan sarana, serta peningkatan mutu lembaga pendidikan agama tersebut (Usman, 2013). 
Pengelolaan Dana pendidikan harus berdasarkan prinsip keadilan, efisiensi, transparansi, dan akuntabilitas publik serta pengalokasian Dana pendidikan. Pengelolaan Dana yang diperoleh dari dari pemerintah maupun dari masyarakat, harus dilandasi semangat akuntabilitas dan transparansi. Begitu pula dengan semua pengeluaran keuangan Pondok Pesantren yang diperoleh dari sumber manapun harus dipertanggungjawabkan. Pertanggungjawaban tersebut menjadi bentuk dari transparasi pengelolaan keuangan. Pada prinsipnya pertanggung jawaban tersebut dilakukan dengan mengikuti aturan dari sumber anggaran. Namun demikian prinsip transparansi dan kejujuran dalam pertanggungjawaban keuangan pondok pesantren harus tetap dijunjung tinggi. Ahunanya (2010) menjelaskan para stakeholder merasa bahwa tidak ada tranparansi dan akuntabilitas pada pendidikan tinggi sehingga tidak ada yang bisa bertanggung jawab atas setiap inefisiensi dalam sistem pendidikan tinggi di Lagos State Nigeria. Subkhan (2012) menjelaskan bahwa peran kyai dalam evaluasi dan pertanggungjawaban terhadap pembiayaan lebih ditekankan pada peranannya sebagai pengaudit atau supervisor keuangan. Arifin dan Raharjo (2013) menganalisis laporan keuangan pondok pesantren hanya menyajikan laporan penerimaan kas dan pengeluaran kas, yang tidak sesuai dengan pos-pos pengklasifikasian yang sesuai dengan standar akuntansi keuangan yang berlaku disebabkan karena yayasan tidak mengenal standar akuntansi yang digunakan sebagai pedoman pelaporan keuangan bagi entitas nirlaba. Begitu pula Yakin (2014) untuk mengatasi masalah di pondok pesantren terutama mengenai pengelolaan keuangan pihak pengelola harus menyusun grand design dan mapping plan yang harus terukur tingkat ketercapaiannya dan atau kegagalannya serta menjamin model opened management.

Beberapa masalah yang dihadapi pesantren disebabkan keterbatasan kemampuan pengelolanya antara lain sarana dan prasarana penunjang yang terlihat masih kurang memadai, keterbatasan sumber daya manusia dalam bidang manajemen kelembagaan serta bidang-bidang lain, manajemen kelembagaan pesantren masih dikelola secara tradisional, kebutuhan keuangan selalu menjadi kendala, serta kurikulum yang berorientasi life skills santri dan masyarakat (Usman, 2013). Umumnya penelitian kompetensi SDM dan akuntabilitas lebih banyak dilakukan di sektor pemerintahan, namun pada penelitian ini dilakukan di pesantren sebagai lembaga pendidikan Islam yang jarang sekali sektor ini dijadikan penelitian. Hal ini dilakukan karena berbagai permasalahan pengelolaan keuangan di pesantren serta melakukan pemecahan permasalahan tersebut melalui penelitian yang dilakukan ini. Berdasarkan pada penelitian diatas maka tujuan pada penelitian ini adalah untuk mengetahui akuntabilitas keuangan di lingkungan pesantren, Untuk mengetahui sejauh mana kompetensi SDM keuangan dalam mempertanggungjawabkan laporan keuangannya di pesantren dan untuk mengetahui pengaruh positif pada kompetensi SDM keuangan terhadap akuntabilitas di pesantren.

\section{Kajian Teori, Literatur dan Pengembangan Hipotesis}

\section{Perencanaan dan pelaksanaan pengelolaan keuangan pondok pesantren}

Pihak pesantren bersama komite atau majelis pesantren pada setiap awal tahun anggaran perlu bersama-sama merumuskan rencana anggaran pendapatan dan biaya sebagai acuan bagi pengelola pesantren dalam melaksanakan, manajemen keuangan yang baik. Anggaran sendiri merupakan rencana yang diformulasikan dalam bentuk rupiah dalam jangka waktu atau periode tertentu, serta alokasi sumber-sumber kepada setiap bagian kegiatan. Anggaran memiliki peran penting di dalam perencanaan, pengendalian dan evaluasi kegiatan yang dilakukan pondok pesantren. Oleh karena itu setiap penanggung jawab program kegiatan di pesantren harus menjalankan kegiatan sesuai dengan anggaran yang telah ditentukan sebelumnya.

Ada dua bagian pokok anggaran yang harus diperhatikan dalam penyusunan RAPBPP, yaitu:

a. Rencana sumber atau target penerimaan/ pendapatan dalam satu tahun yang bersangkutan, termasuk di dalamnya sumber-sumber keuangan dari:

1. Kontribusi santri

2. Sumbangan dari individu atau organisasi

3. Sumbangan dari pemerintah (Bila Ada)

4. Dari hasil usaha pesantren

b. Rencana penggunaan keuangan dalam satu tahun yang bersangkutan. Semua penggunaan keuangan pesantren dalam satu tahun anggaran perlu direncanakan dengan baik agar kehidupan pesantren dapat berjalan dengan baik juga. Penggunaan keuangan pesantren tersebut menyangkut seluruh pengeluaran yang berkaitan dengan kebutuhan pengelolaan pesantren, termasuk untuk Dana operasional harian, pengembangan sarana dan prasarana pesantren, untuk honorarium/gaji/infaq semua petugas/pelaksana di pesantren.
Akuntabilitas
Akuntabilitas merupakan keadaan yang dinilai karena kualitas performansinya dalam menyelesaikan tugas yang menjadi tanggung 
jawabnya. Akuntabilitas adalah kewajibankewajiban dari individu-individu yang dipercayakan untuk mengelola sumber-sumber daya publik serta yang berkaitan dengan itu, guna menjawab hal-hal yang menyangkut pertanggung jawaban fiskal, manajerial, dan program atau kegiatan. (Anggraini, 2013).

Akuntabilitas di dalam penelitian ini berarti pertanggung jawaban terhadap penggunaan Dana BOS yang diperoleh oleh sekolah sebagai satusatunya sumber keuangan dalam program RKAS sebagai sumber Dana yang digunakan untuk kegiatan di sekolah yang dapat dipertanggung jawabkan sesuai dengan perencanaan yang telah ditetapkan. Berdasarkan perencanaan yang telah ditetapkan dan peraturan yang berlaku, maka sekolah membelanjakan uang secara bertanggung jawab (Anggraini, 2013). Oleh karena itu, akuntabilitas akan sulit terlaksana tanpa pemantauan dan partisipasi publik dalam proses pengambilan keputusan. Semakin kecil partisipasi stakeholders dalam penyelenggaraan manajemen sekolah, maka akan semakin rendah pula akuntabilitas sekolah.

Akuntabilitas menurut Trakulmututa (2013) adalah konsep dalam etika dan pemerintahan dengan berbagai arti. Digunakan secara sinonim sebagai tanggung jawab, kesalahan yang tidak disengaja, kewajiban, dan karakteristik lain yang terkait dengan akuntabilitas. Dalam peran kepemimpinan, akuntabilitas adalah pengakuan dan asumsi tanggung jawab atas tindakan, produksi, keputusan, dan kebijakan. Dalam peran kepemimpinan, administrasi, tata kelola, dan implementasi juga termasuk dalam lingkup peran atau posisi pekerjaan dan mencakup kewajiban untuk melaporkan, menjelaskan dan bertanggung jawab atas konsekuensi yang dihasilkan. Lebih lanjut, akuntabilitas administratif terkait dengan aturan dan norma internal.

\section{Kompetensi SDM Keuangan}

Sumber daya manusia merupakan yang berperan dalam menghasilkan informasi. Dalam menghasilkan informasi yang memiliki nilai tentu saja sumber daya manusia yang dimiliki haruslah sumber daya manusia yang memiliki keterampilan serta latar belakang pendidikan dibidang ekonomi akuntansi agar informasi yang dihasilkan tersebut sesuai dengan sistem akuntansi yang berlaku umum, bebas dari kesalahan baik yang material maupun non material dan terhindar dari kecurangan baik yang disengaja maupun tidak disengaja.

Sumber daya manusia yang berkapasitas tinggi tidak hanya dilihat dari latar belakang pendidikannya namun juga dapat dilihat dari pelatihan-pelatihan yang diikuti dan pengalaman dalam suatu bidang pekerjaan tertentu. Jika seorang sumber daya manusia tidak memiliki latar belakang pendidikan yang berkolerasi dengan pekerjaannya tidak dapat dikatakan bahwa sumber daya manusia tersebut tidak memiliki kompetensi, karena kapasitas dari sumber daya manusia bukan hanya diukur dari latar belakang pendidikan namun juga melalui pelatihan dan pengalaman.

Ukuran kapasitas sumber daya manusia dapat dilihat dari rata-rata pendidikan, pelatihan dan tingkat pengalaman (Griffin, 2004 dalam Delanno, 2013) yaitu:

a.Pendidikan

Pendidikan adalah suatu kegiatan yang universal dalam kehidupan manusia, karena dimanapun dan kapan pun didunia terdapat pendidikan.

b. Pelatihan

Pelatihan adalah proses sistematis mengubah tingkah laku seseorang untuk mencapai tujuan organisasi. Pelatihan berkaitan dengan keahlian dan kemampuan untuk melaksanakan pekerjaannya.

c. Pengalaman

Pengalaman dapat dilihat dari lamanya seseorang bekerja. Dengan memiliki pengalaman seseorang akan terbiasa melakukan sesuatu pekerjaan, lebih terampil, punya wawasan yang luas dan mudah beradaptasi dengan lingkungan.

Pada Wijayanti (2017) menjelaskan kompetensi sebagai kemampuan seseorang dalam menghasilkan sesuatu pada tingkat yang memuaskan di tempat kerja, termasuk diantaranya kemampuan seseorang untuk mentransfer dan mengaplikasikan keterampilan dan pengetahuan tersebut dalam situasi yang baru dan meningkatkan manfaat yang disepakati. Seseorang yang memiliki kompetensi akan bekerja dengan pengetahuan dan ketrampilannya sehingga dapat bekerja dengan mudah, cepat, intuitif dan dengan pengalamannya bisa meminimalisir kesalahan. Tiga kecenderungan ini juga selaras dengan pengertian kompetensi dalam penjelasan PP No. 101 Tahun 2000 pasal 3 bahwa, yang dimaksud dengan kompetensi adalah kemampuan dan karakteristik yang dimiliki oleh PNS berupa pengetahuan, keterampilan dan sikap perilaku yang diperlukan dalam pelaksanaan tugas jabatannya.

Pada Wijayanti (2017) terdapat Hutapea dan Thoha (2008), mengungkapkan bahwa ada tiga komponen utama pembentukan kompetensi yaitu pengetahuan yang dimiliki seseorang, ketrampilan dan perilaku individu. (1) Pengetahuan (knowledge) adalah informasi yang dimiliki seseorang karyawan untuk melaksanakan tugas dan tanggung jawabnya sesuai dengan bidang yang digelutinya (tertentu). Pengetahuan karyawan turut menentukan berhasil 
tidaknya pelaksanaan tugas yang dibebankan kepadanya, karyawan yang mempunyai pengetahuan yang cukup akan meningkatkan efisiensi organisasi. Namun bagi karyawan yang belum mempunyai pengetahuan yang cukup, maka akan bekerja tersendat-sendat; (2) Ketrampilan (skill) merupakan suatu upaya untuk melaksanakan tugas dan tanggung jawab yang diberikan perusahaan kepada seorang karyawan dengan baik dan maksimal; (3) Sikap (attitude) merupakan pola tingkah laku seorang karyawan/pegawai didalam melaksanakan tugas dan tanggungjawabnya sesuai dengan peraturan organisasi. Apabila karyawan mempunyai sifat yang mendukung pencapaian tujuan organisasi, maka secara otomatis segala tugas yang dibebankan kepadanya akan dilaksanakan dengan sebaik-baiknya.

\section{Pesantren}

Pesantren sebagai lembaga pendidikan Islam mengalami perkembangan bentuk sesuaidengan perubahan zaman, terutama adanya kemajuan ilmu pengetahuan dan teknologi. Perubahan bentuk pesantren bukan berarti pesantren kehilangan ciri khasnya. Sistem pesantren adalah sarana yang berupa perangkat organisasi yang diciptakan untuk mencapai tujuanpendidikan yang berlangsung dalam pesantren.

Tipe pesantren menurut Usman (2013) berdasarkan kurikulum atau sistem pendidikan yang dipakai mempunyai 3 tipe yaitu (1) Pesantren Tradisional (salāf) adalah Pesantren ini masih mempertahankan bentuk aslinya dengan mengajarkan kitab yang ditulis oleh ulama abad ke-15 dengan menggunakan bahasa Arab. Sistem pengajarannya adalah penghapalan yang titik akhirnya dari segi metodologi cenderung kepada terciptanya santri yang menerima dan memiliki ilmu. Artinya ilmu tidak berkembang ke arah paripurnanya ilmu itu, melainkan hanya terbatas pada apa yang diberikan kyai. Kurikulum sepenuhnya ditentukan oleh para kyai pengasuh pondok. (2) Pesantren Modern adalah pesantren ini merupakan pengembangan tipe pesantren karena orientasi belajarnya cenderung mengadopsi seluruh sistem belajar klasikal dan meninggalkan sistem belajar tradisional. Kurikulum yang dipakai adalah kurikulum nasional. (3) Pesantren Komprehensif adalah tipe pesantren dengan sistem pendidikan dan pengajaran gabungan antara tradisional dan modern. Pendidikan diterapkan dengan pengajaran kitab kuning dengan metode sorongan, bandongan dan wetonan yang biasanya diajarkan pada malam hari sesudah salat Magrib dan sesudah salat Subuh. Proses pembelajaran sistem klasikal dilaksanakan pada pagi sampai siang hari seperti di madrasah/sekolah pada umumnya.

\section{Kerangka Pemikiran}

Penelitian ini dilakukan di Pesantren sebagai Lembaga Pendidikan Islam. Pertanggungjawaban pada pesantren menjadi bentuk dari akuntabilitas pengelolaan keuangan. Namun demikian prinsip transparansi dan kejujuran dalam pertanggung jawaban keuangan pondok pesantren harus tetap dijunjung tinggi. Keterbatasan kemampuan pengelolanya, seperti sarana dan prasarana penunjang yang menurut Yakin (2014) menerapkan kehati-hatian berhubungan erat dengan masalah pembiayaan atau penDanaan dan keterbukaan yang dikedepankan karena masalah perencanaan sarana prasarana ini bersumber dari masukan dan permintaan guru, pegawai atau bahkan juga siswa. Keterbatasan sumber daya manusia dalam bidang manajemen kelembagaan dan bidang-bidang lain, dalam hal ini manajemen kelembagaan pesantren masih dikelola secara tradisional, serta kebutuhan keuangan selalu menjadi kendala. Semua pengeluaran keuangan Pondok Pesantren yang diperoleh dari sumber manapun harus dipertanggungjawabkan. Pertanggungjawaban tersebut menjadi bentuk dari transparasi pengelolaan keuangan. Pada prinsipnya pertanggung jawaban tersebut dilakukan dengan mengikuti aturan dari sumber anggaran. Namun demikian prinsip transparansi dan kejujuran dalam pertanggungjawaban keuangan pondok pesantren harus tetap dijunjung tinggi.

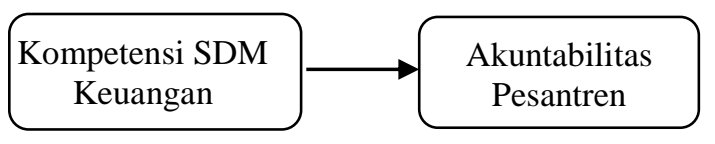

Gambar 1. Kerangka Pemikiran

\section{Perumusan Hipotesis}

Pengaruh Positif pada Kompetensi SDM Keuangan terhadap Akuntabilitas Pesantren. Pada Riantiarno (2011) terdapat Soleman (2007) menyimpulkan bahwa kompetensi aparatur pemerintah daerah, penerapan akuntabilitas keuangan, dan ketaatan terhadap perundangan mempunyai pengaruh yang signifikan terhadap akuntabilitas kinerja instansi Pemerintah. Hasil peneilitian ini menyimpulkan bahwa variabel kompetensi aparatur pemerintah memiliki pengaruh yang signifikan terhadap akuntabilitas kinerja instansi pemerintah. Semakin tinggi kompetensi aparatur pemerintah maka akan berpengaruh pada penerapan akuntabilitas kinerja instansi pemerintah daerah secara baik dan memadai (Zirman, 2010). Pada Febrianto (2017) terdapat Aini (2014) konsisten dengan hasil penelitian Rismawati (2015), yang menunjukkan bahwa kompetensi aparatur pemerintah berpengaruh positif terhadap akuntabilitas kinerja instansi pemerintah. Penelitian Pratiwi (2017) 
menyimpulkan nilai t hitung positif menun jukkan bahwa variabel pengelolaan keuangan mempunyai hubungan yang searah dengan akuntabilitas kinerja pada kantor instansi pemerintah daerah Kota Semarang. Berdasarkan hasil tersebut dapat dikatakan bahwa variabel penge lolaan keuangan berpengaruh positif signifikan terhadap akuntabilitas kineja pada kantor instansi pemerintah daerah.

H1: Kompetensi SDM keuangan berpengaruh positif terhadap Akuntabilitas Pesantren

\section{Metode Penelitian}

\section{Jenis dan sumber data}

Penelitian ini menggunakan data primer dengan mendatangi langsung lokasi penelitian untuk memperoleh data-data yang diperlukan melalui observasi dengan wawancara pada pengurus pengelolaan keuangan dan penyebaran kuesioner kepada 116 responden yang terdiri dari guru dan pengurus pengelolaan keuangan. Observasi dilakukan peneliti secara acak terhadap pengelolaan keuangan Pondok Pesantren di Jabodetabek yang bersedia untuk dilakukan sebagai objek penelitian yaitu Pesantren Daarul Rahman Jakarta Selatan, Pesantren Sirojul Munir Bekasi, Pesantren Al Hidayah Kembangan Jakarta Barat, Pesantren Ashoulatiyah Nahdlatul Wathan Tangerang - Banten, Pesantren Putri Hasmi Bogor dan Pesantren Qotrunada Depok.

\section{Populasi dan Sampel}

Populasi dalam penelitian ini adalah seluruh pegawai yang berada di pesantren yang berjumlah 300 responden. Sehingga rata-rata pegawai yang dimiliki oleh masing-masing pesantren adalah 50 pegawai. Teknik pengambilan sampel menggunakan metode purposive sampling, yaitu pengambilan sampel secara terpilih sesuai dengan kriteria penelitian. Kriterianya adalah pimpinan sekolah, kepala bagian TU, kepala sub bagian, guru, dan staf akuntansi dan keuangan yang terlibat dalam penyusunan anggaran dan laporan keuangan dengan jumlah sampel sebesar 116 responden.

\section{Definisi Operasional Variabel dan Pengukuran Akuntabiitas}

Akuntabilitas adalah kewajiban-kewajiban dari individu-individu yang dipercayakan untuk mengelola sumber-sumber daya publik serta yang berkaitan dengan itu, guna menjawab hal-hal yang menyangkut pertanggung jawaban fiskal, manajerial, dan program atau kegiatan.
Indikator akuntabilitas yang digunakan (Muhammad, Hamid (2007) dalam Puruwita, 2015) adalah Meningkatnya kepercayaan dan kepuasan masyarakat pemerintah, Meningkatnya keterwakilan berdasarkan pilihan, dan berkurangnya kasus-kasus korupsi kolusi dan nepotisme (KKN).

\section{Kompetensi SDM Keuangan}

Kompetensi SDM Keuangan adalah kemampuan seseorang dalam menghasilkan sesuatu pada tingkat yang memuaskan di tempat kerja, termasuk diantaranya kemampuan seseorang untuk mentransfer dan mengaplikasikan keterampilan dan pengetahuan tersebut dalam situasi yang baru dan meningkatkan manfaat yang disepakati.

Indikator kompetensi SDM keuangan yang digunakan (Murdayanti, 2013 dan Wijayanti, 2017) adalah pengetahuan yang dimiliki seseorang, ketrampilan dan perilaku atau sikap individu.

\section{Metode Analisis Data}

Analisis deskriptif ini merupakan analisis yang mengemukakan tentang data diri responden, yang diperoleh dari jawaban responden melalui kuesioner dan wawancara. Analisis deskriptif kualitatif bertujuan untuk mengungkapkan kejadian atau fakta, keadaan, fenomena, variabel dan keadaan yang terjadi saat penelitian berlangsung dengan menyuguhkan apa yang sebenarnya terjadi.

Uji kualitas data dilakukan melalui Uji Validitas digunakan untuk mengukur sah atau valid tidaknya suatu kuesioner. Suatu kuesioner dikatakan valid jika pertanyaan pada kuesioner mampu untuk mengungkapkan sesuatu yang akan diukur oleh kuesioner tersebut dan Uji Reliabilitas dimaksudkan untuk menguji konsistensi kuesioner dalam mengukur suatu konstruk yang sama dan suatu kuesioner dinyatakan reliabel atau handal jika jawaban seseorang terhadap pernyataan adalah konsisten atau stabil dari waktu ke waktu (Ghozali, 2014).

Uji regresi linier adalah salah satu dari jenis analisis peramalan atau prediksi yang sering digunakan pada data berskala kuantitatif (interval atau rasio). Analisis regresi mempelajari bentuk hubungan antara satu atau lebih peubah atau variabel bebas $(\mathrm{X})$ dengan satu peubah tak bebas (Y) dengan alat analisis program SPSS (Statistical Product and Service Solution) (Ghozali, 2014).

\section{Analisa Dan Pembahasan}




\section{Deskripsi Responden}

Responden yang diperoleh akan dijelaskan dan diklasifikasikan berdasarkan karakteristik masingmasing yang tertera pada tabel dibawah ini:

TABEL 1.

DESKRIPSI RESPONDEN

\begin{tabular}{|l|l|l|l|}
\hline $\begin{array}{c}\text { Karakteristik } \\
\text { Responden }\end{array}$ & \multicolumn{1}{|c|}{ Tipe } & Frekuensi & $\%$ \\
\hline Jenis Kelamin & Laki-Laki & 54 & 46.6 \\
\hline & Perempuan & 62 & 53.4 \\
\hline Jabatan & Ketua & 3 & 2.6 \\
\hline & Bendahara & 16 & 13.8 \\
\hline & Guru & 48 & 41.4 \\
\hline & Pengurus & 49 & 42.2 \\
\hline Masa Jabatan & $<2$ tahun & 64 & 55.2 \\
\hline & $2-5$ tahun & 17 & 14.7 \\
\hline & $>5$ tahun & 35 & 30.2 \\
\hline Pendidikan Terakhir & D3 & 2 & 1.7 \\
\hline & S1 & 52 & 44.8 \\
\hline & S2 & 2 & 1.7 \\
\hline & SMA/Sederajat & 48 & 41.4 \\
\hline & SMP/Sederajat & 12 & 10.3 \\
\hline
\end{tabular}

Pada tabel 1 dijelaskan terdapat jumlah wanita 53.4 $\%$ lebih banyak bekerja di pesantren. Perbedaan kepribadian yang mendasar antara wanita dan pria adalah pria pada umumnya bersifat individualis, agresif, kurang sabar, lebih tegas, rasa percaya diri lebih tinggi dan lebih menguasai pekerjaan sedangkan wanita cendrung lebih perhatian kepada orang lain, penurut, pasif, lebih mengedepankan perasaan dan mempunyai tanggung jawab mengurus keluarga yang lebih besar dari pada pria. Sehingga dengan perbedaan ini maka pesantren lebih banyak menugaskan karyawan wanita karena bersikap penurut dan teliti dalam mengerjakan pekerjaannya.

Perbedaan jabatan seimbang antara guru dan pengurus sehingga terdapat keselarasan dalam usaha mencapai tujuan perusahaan. Masa kerja sangat mempengaruhi penguasaan rincian pekerjaan dari seorang karyawan, dalam hal ini responden dengan masa kerja yang lebih lama mempunyai pengalaman, kepercayaan diri dan penguasaan job description yang lebih baik (Robbins, 2016). Dari tabel terdapat masa kerja lebih dari 5 tahun sehingga diketahui bahwa karyawan tersebut memiliki kemampuan, pengetahuan, tanggung jawab dalam bertindak, berpikir serta mengambilan keputusan yang lebih baik.

Pada deskripsi responden pendidikan terakhir lebih banyak pada karyawan dengan pendidikan S1 sebesar $44.8 \%$ dengan latar pendidikan yang berbeda tersebut akan mempengaruhi kemampuan, wawasan dan tingkat kepercayaan diri dari responden dalam melaksanakan pekerjaannya. Hal tersebut dikarenakan pendidikan sangat penting guna meningkatkan kemampuannya. Responden dengan tingkat pendidikan yang tinggi mampu bekerja dengan tingkat kesulitan dan tanggung jawab yang lebih tinggi (Robbins, 2016)

\section{Akuntabilitas Keuangan Pesantren}

Akuntabilitas dijelaskan dengan menggunakan hasil analisis regresi yang menguji pengaruh Kompetensi SDM keuangan terhadap Akuntabilitas Pesantren. Indikator yang digunakan pada variabel akuntabilitas berdasarkan penelitian Puruwita (2015) dan Murdayanti (2013), adapun hasil pengujiannya sebagai berikut:

TABEL 2.

UJI VALIDITAS DAN REABILITAS VARIABEL AKUNTABILTAS

\begin{tabular}{|l|l|l|l|}
\hline \multicolumn{1}{|c|}{$\begin{array}{c}\text { Reliability } \\
\text { Statistics }\end{array}$} & $\begin{array}{c}\text { Cronbach's } \\
\text { Alpha }\end{array}$ & N of Items & Description \\
\hline Validity Statistics & $\begin{array}{l}\text { Pearson } \\
\text { Correlation }\end{array}$ & Significant & Reliable \\
\hline $\begin{array}{l}\text { AKUNTABILITAS } \\
3\end{array}$ & 0.126 & 0.177 & $\begin{array}{l}\text { Tidak } \\
\text { Valid }\end{array}$ \\
\hline $\begin{array}{l}\text { AKUNTABILITAS } \\
12\end{array}$ & 0.143 & 0.125 & $\begin{array}{l}\text { Tidak } \\
\text { Valid }\end{array}$ \\
\hline
\end{tabular}

Pada tabel 2, uji validitas yaitu menguji suatu taraf untuk dapat mengukur apa yang seharusnya diukur, sehingga suatu penelitian yang menggunakan kuesioner sebagai alat pengukurnya perlu diuji validitasnya. Pada uji ini digunakan sampel sebanyak 116 responden dan terdapat 2 butir pernyataan yang tidak valid.

Sedangkan uji reliabilitas mengukur sebuah instrumen dapat mengukur sesuatu yang diukur secara konsisten dari waktu ke waktu. Dari hasil tersebut menunjukkan tingkat reabilitas instrument yang berjumlah 12 butir sebagai instrument final yang mengukur akuntabilitas. Nilai reliabilitas dari variabel transparansi adalah 0.760 lebih besar dari 0.70 yang artinya instrument pernyataan ini reliabel dan dapat dipergunakan sebagai pengumpul data yang handal.

Pada tabel 3 menunjukkan rata-rata dari setiap butir pernyataan berada pada kategori penilaian yang baik. Skor terendah dimiliki oleh AKUNTABILITAS 5 sebesar 3.38 mengenai pernyataan tentang Menurut saya organisasi melaksanakan Pernyataan Standar Akuntansi Keuangan 45 untuk organisasi nir laba dalam membuat laporan keuangan bahwa Semua pondok pesantren ini memiliki prosedur keuangan dilakukan secara sederhana dan tidak menganut adanya pernyataan standar akuntansi keuangan untuk organisasi nirlaba. Dijelaskan bahwa pada hasil kuesioner dan wawancara bahwa Standard Operation Procedure (SOP) keuangan di semua pesantren yang diobservasi sudah dilakukan dan tertulis yang semuanya sudah diatur oleh kyai sebagai pimpinan pesantren. Salah satu contoh prosedur keuangan yaitu pada kartu pembayaran 
buku besar uang yang diperoleh dari hasil hukuman santri akan dikumpulkan dan dicatat dalam buku besar, disetor ke kas pesantren, kemudian digunakan kembali untuk kesejahteraan santri seperti beli beras, lauk pauk, dan sebagainya.

TABEL 3

Penilaian Indikator AKUntabilitas

\begin{tabular}{|l|l|l|l|}
\hline \multicolumn{1}{|c|}{ Indikator } & Butir Pernyataan & Score & Mean \\
\hline $\begin{array}{l}\text { Meningkatnya } \\
\text { kepercayaan } \\
\text { dan kepuasan } \\
\text { masyarakat } \\
\text { terhadap } \\
\text { organisasi }\end{array}$ & AKUNTABILITAS 1 & 415 & 3.58 \\
\cline { 2 - 4 } & AKUNTABILITAS 2 & 474 & 4.09 \\
\hline $\begin{array}{l}\text { Kualitas } \\
\text { keuangan } \\
\text { sesuai dengan } \\
\text { penerapan visi, } \\
\text { misi, hasil dan } \\
\text { manfaat yang } \\
\text { diperoleh }\end{array}$ & AKUNTABILITAS 4 & & \\
\hline $\begin{array}{l}\text { Berkurangnya } \\
\text { kasus-kasus } \\
\text { korupsi, kolusi } \\
\text { dan nepotisme } \\
\text { (KKN) }\end{array}$ & AKUNTABILITAS 5 & 392 & 3.38 \\
\cline { 2 - 4 } & AKUNTABILITAS 6 & 455 & 3.92 \\
\cline { 2 - 4 } & AKUNTABILITAS 7 & 458 & 3.95 \\
\cline { 2 - 4 } & AKUNTABILITAS 8 & 452 & 3.90 \\
\cline { 2 - 4 } & AKUNTABILITAS 9 & 484 & 4.17 \\
\cline { 2 - 4 } & AKUNTABILITAS 10 & 440 & 3.79 \\
\cline { 2 - 4 } & AKUNTABILITAS 11 & 462 & 3.98 \\
\cline { 2 - 4 } & AKUNTABILITAS 13 & 478 & 4.12 \\
\cline { 2 - 4 } & AKUNTABILITAS 14 & 438 & 3.78 \\
\hline
\end{tabular}

Namun terdapat beberapa pesantren yang tidak melakukan Perumusan Rencana Anggaran Pendapatan dan Belanja, semua pengeluaran dilakukan sesuai dengan kebutuhan dan dibutuhkan kapanpun. Sehingga tidak ada pengesahan pengeluaran dan semua nya diatur oleh Kyai.

Dalam mencari alternatif penDanaan, umumnya pondok pesantren hanya befokus pada Dana Kyai yang rata-rata diperoleh dari modal kyai, donator, ataupun amal para masyarakat sekitar, misalnya sumber daya internal dilakukan oleh santri, sedangkan eksternal dilakukan oleh alumni ataupun dari pihak pondok pesantren mengirimkan proposal kepada pemerintah daerah bilamana membutuhkan dukungan Dana berupa alat kebersihan. Kemudian dari pemerintah setempat mengirimkan bantuan berupa tempat sampah untuk pesantren. Adanya sumber Dana mandiri biasanya dari santri ataupun pimpinan pondok pesantren yang langsung memberikan Dana serta sumber Dana pemerintah.

Sedangkan skor tertinggi terdapat pada butir AKUNTABILITAS 9 sebesar 4.17 mengenai organisasi membuat sistem anggaran yang baik sesuai dengan peraturan yang berlaku dengan ratarata menjawab setuju yang berarti bahwa pesantren sudah membuat sistem anggaran yang baik dengan peraturan yang tertulis dan disahkan pimpinan pesantren dan tidak ada pemberitahuan kepada pihak eksternal mengenai laporan keuangan yang sudah diaudit. Dokumentasi (pembukuan) setiap penggunaan anggaran seperti catatan kegiatan santri, manual, buku tabungan santri \& buku pembukuan makan tercatat dengan baik serta disesuaikan dengan kebutuhannya. Laporan pertanggungjawaban keuangan dibuat satu tahun sekali. Setiap bendahara tiap bagian tersebut akan berkoordinasi dengan bendahara pusat.

Hasil lain dari pembuktian kuesioner terhadap responden juga diperoleh informasi bahwa rata-rata responden menjawab pesantren sudah melaporkan laporan keuangannya secara tepat waktu dan memiliki dokumentasi bukti-bukti pengeluaran keuangan dengan baik. Pesantren juga mengumumkan laporan penyerapan Dana baik di papan pengumuman dan juga dilaporkan kepada para stakeholder secara periodik sebagai bentuk transparansi dan akuntabilitas kepada pemilik pesantren dan stakeholder.

\section{Kompetensi SDM Keuangan}

Kompetensi SDM Keuangan dijelaskan dengan menggunakan hasil kuesioner dan wawancara berdasarkan persepsi responden pada masingmasing pernyataan. Indikator yang digunakan pada variabel kompetensi SDM Keuangan berdasarkan penelitian Murdayanti (2013) dan Wijayanti (2017), adapun hasil pengujiannya sebagai berikut:

TABEL 4.

UJI REABILITAS KOMPETENSI SDM KEUANGAN

\begin{tabular}{|r|r|}
\hline \multicolumn{2}{|c|}{ Reliability Statistics } \\
\hline Cronbach's Alpha & N of Items \\
\hline .874 & \\
\hline
\end{tabular}

Pada tabel 4, terdapat uji reliabilitas mengukur sebuah instrumen dapat mengukur sesuatu yang diukur secara konsisten dari waktu ke waktu. Dari hasil tersebut menunjukkan tingkat reabilitas instrument yang berjumlah 17 butir sebagai instrument final yang mengukur kompetensi SDM keuangan. Nilai reliabilitas dari variabel transparansi adalah 0.874 lebih besar dari 0.70 yang artinya instrument pernyataan ini reliabel dan dapat dipergunakan sebagai pengumpul data yang handal.

TABEL 5 .

PENILAIAN INDIKATOR KOMPETENSI SDM KEUANGAN

\begin{tabular}{|l|l|l|l|}
\hline \multicolumn{1}{|c|}{ Indikator } & $\begin{array}{c}\text { Butir } \\
\text { Pernyataan }\end{array}$ & Score & Mean \\
\hline Pengetahuan & SDM1 & 430 & 3.71 \\
\cline { 2 - 4 } & SDM2 & 390 & 3.36 \\
\hline Keahlian/Keterampilan & SDM3 & 446 & 3.84 \\
\cline { 2 - 4 } & &
\end{tabular}




\begin{tabular}{|l|l|l|l|}
\hline \multirow{5}{*}{} & SDM4 & 433 & 3.73 \\
\cline { 2 - 4 } & SDM5 & 369 & 3.18 \\
\cline { 2 - 4 } & SDM6 & 443 & 3.82 \\
\cline { 2 - 4 } & SDM7 & 384 & 3.31 \\
\cline { 2 - 4 } & SDM8 & 371 & 3.20 \\
\cline { 2 - 4 } & SDM9 & 385 & 3.32 \\
\cline { 2 - 4 } & SDM10 & 381 & 3.28 \\
\hline Sikap & SDM11 & 414 & 3.57 \\
\cline { 2 - 4 } & SDM12 & 423 & 3.65 \\
\hline & SDM13 & 436 & 3.76 \\
\hline & SDM14 & 368 & 3.17 \\
\hline & SDM15 & 433 & 3.73 \\
\cline { 2 - 4 } & SDM16 & 434 & 3.74 \\
\cline { 2 - 4 } & SDM17 & 465 & 4.01 \\
\hline
\end{tabular}

Pada tabel 5 menunjukkan rata-rata dari setiap butir pernyataan berada pada kategori penilaian yang baik. Skor terendah dimiliki oleh SDM 14 sebesar 3.17 mengenai pernyataan tentang saya selalu mengikuti pelatihan terkait pencatatan laporan keuangan. Hasil kuesioner ini didukung oleh penelian Arifin dan Raharjo (2013) serta Usman (2013) bahwa kendala SDM di pesantren adalah kurangnya pemahaman mengenai keuangan itu sendiri dikarenakan banyaknya pegawai yang bukan lulusan dari pendidikan keuangan. Dalam penerapan pertanggung jawaban keuangan umumnya dilakukan berdasarkan pada pencatatan harga pasar dan pencatatan bersumber pada harga perkiraan terhadap suatu kejadian atau transaksi keuangan, sehingga bentuk pelaporan keuangan berlandaskan basis kas yaitu pencatatan yang bersumber pada penerimaan kas (cash in) dan pengeluaran kas (cash out). Begitu pula adanya pemisahan fungsi yang tegas dan belum terorganisir dengan baik dalam hal pengelolaan keuangan hanya berdasarkan kepercayaan dan kemampuan pengurus dalam melaksanakan tugasnya. Kepercayaan dan kekeluargaan menjadi poin penting dalam semua pelaksanaan kegiatan pesantren. Pengelolaan Keuangan yang dilakukan di pesantren ini masih dilakukan pencatatan secara manual, adapun transaksi yang dilakukan dengan komputer bersifat kepada penerimaan dan pengeluaran Dana saja.

Sedangkan skor tertinggi terdapat pada butir SDM 17 sebesar 4.01 mengenai pernyataan bahwa organisasi selalu menyediakan Dana-Dana dianggarkan untuk memperoleh sumber daya, peralatan, pelatihan yang dibutuhkan. Pada Azmy (2015), Kompetensi sangat dibutuhkan untuk menghadapi perubahan lingkungan yang cepat. Sustainabilitas organisasi dapat dipertahankan bergantung pada kemampuan organisasi untuk beradaptasi dengan perubahan. Organisasi harus mampu merumuskan jenis kompetensi yang dibutuhkan oleh anggota organisasi untuk beradaptasi dengan tren bisnis yang sedang berkembang sehingga mampu menghasilkan ideide atau inovasi baru untuk menjaga persaingan dengan para kompetitor. Kompetensi dan perubahan organisasi harus dilakukan sesuai dengan permintaan dan kebutuhan lingkungan. Didukung pula oleh Trakulmututa (2013) bahwa dalam penelitiannya Pemerintah Pusat harus mendesentralisasikan kewenangannya dalam legislasi kepada pemerintah daerah untuk pemerintah tingkat lokal untuk menentukan kebijakan publik, kebijakan fiskal, dan manajemen sumber daya manusia yang menyesuaikan perkembangan provinsi dan pembangunan negara secara keseluruhan. Sedangkan dalam mengatur proses tata kelola yang baik diperlukan pengelolaan sumber daya manusia yang merupakan hasil dari proses desentralisasi kewenangan.

Dengan keunikan yang dimiliki pesantren, pimpinan selalu mengupayakan untuk memberikan pengembangan SDM nya agar lebih berkualitas bahkan terdapat beberapa pegawainya yang dibiayai untuk menempuh studi lanjut yang lebih tinggi. Hal ini didukung oleh kekeluargaan yang merupakan prinsip penting dalam pesantren bahwa segala kekurangan dan kesulitan dalam penyediaan Dana selalu dapat diatasi dan yakin bahwa dengan Dana yang terbatas pasti akan tercapai semua tujuan yang sudah direncanakan dengan memegang teguh prinsip kepercayaan dan yakin pada Allah SWT. Sama halnya pada Charlton (2009-2010) yang mendeskripsikan hubungan antara retensi guru, akuntabilitas resiprokal, kepemimpinan yang efektif dan keselarasan sumber daya manusia adalah semua bagian dari teka-teki yang luas yang harus disesuaikan untuk perkembangan organisasi. Kualitas setiap elemen bergantung pada kualitas yang lain. Koneksi berdampak pada organisasi dan mengubahnya dari biasa menjadi luar biasa. Individu yang memimpin organisasi yang luar biasa adalah orang-orang yang organik dan dinamis yang menggunakan praktik kepemimpinan ilmiah serta seni untuk melakukan perubahan.

\section{Pengaruh Kompetensi SDM Keuangan Terhadap Akuntabilitas Pesantren}

Berdasarkan hasil analisis regresi linier berganda pada tabel 6, maka dapat diketahui model regresi yang dapat dibentuk sebagai berikut:

AKUNTABILITAS $=33.306+0.304$ SDM

UJI REGERESI LINIER SEDERHANA 


\begin{tabular}{|c|c|c|c|c|c|}
\hline \multirow{2}{*}{$\begin{array}{c}\text { Variabel } \\
\text { Independent }\end{array}$} & \multicolumn{2}{|c|}{$\begin{array}{l}\text { Unstandardized } \\
\text { Coefficients }\end{array}$} & \multirow{2}{*}{$\begin{array}{c}\text { Standardized } \\
\text { Coefficients } \\
\text { Beta }\end{array}$} & \multirow[t]{2}{*}{$\mathrm{T}$} & \multirow[t]{2}{*}{ Sig } \\
\hline & B & $\begin{array}{l}\text { Std. } \\
\text { Error }\end{array}$ & & & \\
\hline (Constant) & 33.306 & 3.107 & & 10.718 & .000 \\
\hline SDM & .304 & .051 & .488 & 5.964 & $.000 * *$ \\
\hline $\begin{array}{l}\text { Adjusted R } \\
\text { Square }\end{array}$ & \multicolumn{5}{|c|}{.231} \\
\hline R Square & \multicolumn{5}{|c|}{.238} \\
\hline Sig & \multicolumn{5}{|c|}{.000} \\
\hline $\mathrm{F}$ & \multicolumn{5}{|c|}{35.571} \\
\hline
\end{tabular}

Dari hasil analisis regresi sederhana diperoleh nilai adjusted $r$ square sebesar 0.231 atau $23.1 \%$. Hasil tersebut menunjukkan bahwa variabel independen yang terdiri dari kompetensi SDM keuangan mampu menjelaskan variabel dependen yaitu akuntabilitas sebesar $23.1 \%$. Sedangkan sisanya $76.9 \%$ dijelaskan oleh variabel-variabel lainnya di luar variabel penelitian seperti penggunaan teknologi informasi, kepemimpinan, motivasi kerja, transparansi dan ketaatan terhadap peraturan yang berlaku di organisasi.

Pada hasil uji parsial diketahui bahwa kompetensi SDM keuangan berpengaruh positif dan signifikan terhadap Akuntabilitas dengan tingkat signifikansi dibawah 0.050 yaitu 0.000 . Hasil dari uji regresi diatas menyimpulkan bahwa Sumber daya manusia (SDM) yang kompeten tersebut akan mampu memahami logika akuntansi dengan baik. Indriasari (2008) menyatakan kegagalan sumber daya manusia pemerintah daerah dalam memahami dan menerapkan logika akuntansi akan berdampak pada kekeliruan laporan keuangan yang dibuat dan ketidaksesuaian laporan dengan standar yang ditetapkan pemerintah. Didukung pula pada penelitian Pratiwi (2017) bahwa pengelolaan keuangan mempunyai pengaruh positif dan signifikan terhadap peningkatan akuntabilitas kinerja pada Kantor instansi pemerintah daerah Kota Semarang. Serta Azmy (2015) bahwa peningkatan kompetensi diperlukan untuk mencapai tujuan organisasi. Perubahan dan pengembangan organisasi memerlukan kompetensi yang harus dimiliki anggota organisasi. Kompetensi memberikan kontribusi positif bagi pencapaian organisasi. Anggota organisasi memerlukan pelatihan dan pengembangan kemampuan demi pencapaian tujuan organisasi secara keseluruhan. Didukung pula oleh hasil penelitian Trakulmututa (2013) ditemukan bahwa pencapaian Tata Kelola yang baik yang diukur dengan dimensi peraturan hukum, manfaat peraturan (rule of merit), peraturan partisipasi, peraturan transparansi dan peraturan akuntabilitas terhadap manajemen sumber daya manusia pemerintah daerah di Bagian Selatan Thailand dengan tingkat level signifikansi tertinggi adalah peraturan hukum.
Berdasarkan data deskripsi responden, terdapat fakta bahwa jumlah pegawai yang memiliki jabatan sebagai bendahara masih kurang. Uraian tugas dan fungsi yang ada juga masih terlalu umum (belum terspesifikasi dengan jelas), sedangkan fungsi dan proses akuntansi hanya dapat dilaksanakan oleh pegawai yang memiliki pengetahuan di bidang ilmu akuntansi. Namun dengan sedikitnya jumlah pegawai dengan latar belakang keuangan atau tanpa pegawai dengan lulusan akuntansi, tidak mempengaruhi kualitas laporan keuangan sederhana yang dihasilkan. Hal tersebut dibuktikan oleh adanya rekapitulasi laporan pertanggungjawaban keuangan yang dibuat secara periodik. Serta didukung oleh kegiatan monitoring evaluasi yang dilakukan oleh pihak pesantren secara berkala setiap sebulan sekali dan paling lama adalah selama satu semester. Walaupun kelemahan yang ada diimbangi dengan mengikutsertakan pegawai dalam pelatihan-pelatihan yang berhubungan dengan akuntansi dan pengelolaan keuangan, terbukti bahwa pesantren selalu mengupayakan pengembangan dan mengoptimalkan kualitas SDM nya. Seperti penelitian Murthy (2012) yang menjelaskan seorang pemimpin harus lebih berkonsentrasi pada kegiatan pelatihan dan pengembangan dan harus mengetahui kebutuhan kemampuan dalam proses bisnis dan mengevaluasi berbagai jenis pelatihan seperti memilih lokakarya dengan topic yang spesifik, program pelatihan di luar ruang kelas, seminar pendidikan eksekutif, pembelajaran jarak jauh dan sebagainya untuk memperdalam kemampuan yang dibutuhkan di antara para pegawai.

\section{Kesimpulan dan Saran}

\section{Kesimpulan}

Hasil dari penelitian ini berdasarkan penilaian indikator akuntabilitas bahwa pelaksanaan keuangan di pesantren telah diterapkan dengan adanya dokumentasi pada penggunaan anggaran. Pesantren pada umumnya sudah membuat sistem anggaran yang baik namun belum sesuai dengan standar akuntansi keuangan yang berlaku untuk organisasi nirlaba dalam penyusunan laporan keuangannya.

Laporan pertanggungjawaban keuangan juga telah dibuat secara periodik sebagai bentuk transparansi dan akuntabilitas kepada pemilik pesantren dan stakeholder. Semua data baik data internal, program kerja, keuangan dan laporan kegiatan telah terdokumentasikan dengan baik walaupun belum semua pencatatan tercatat secara komputerisasi. Kelemahan yang dimiliki pesantren hanyalah pada sumber daya manusia yang masih minim pengetahuannya dalam bidang akuntansi keuangan 
sehingga sulit untuk melakukan pencatatan keuangan sesuai standar akuntansi yang berlaku, hal tersebut didukung oleh karyawan yang tidak semuanya berasal dari lulusan akuntansi.

Begitu pula pada hasil uji bahwa kompetensi SDM keuangan berpengaruh positif dan signifikan terhadap Akuntabilitas dengan menyimpulkan bahwa Sumber daya manusia (SDM) yang kompeten tersebut akan mampu memahami logika akuntansi dengan baik. Semakin tinggi SDM keuangan maka akan berpengaruh pada penerapan akuntabilitas pesantren secara baik dan memadai.

\section{Saran}

Saran dari penelitian ini dalam pengelolaan keuangan diharapkan semua kegiatan operasional pesantren memiliki anggaran yang disepakati sebelum masuk tahun ajaran baru dengan kesepakatan pimpinan, pengurus akuntansi dan keuangan serta para pemangku kepentingan serta mempublikasikan laporan tahunan pesantren dengan melibatkan para orang tua santri sehingga dapat lebih meningkatkan transparansi dan akuntabilitas, pencatatan keuangan lebih baik dilakukan sesuai dengan standar akuntansi keuangan yang berlaku untuk lebih mudah dipahami oleh pemakai laporan keuangan pesantren, dan memberdayakan SDM pesantren dengan memberikan pelatihan pengelolaan keuangan dan praktik-praktik akuntansi serta memanfaatkan program aplikasi penyusunan laporan keuangan berbasis komputer dan disosialisasikan kembali mengingat penggunaan program tersebut mampu menghemat waktu dan memberikan informasi yang lebih akurat dan handal.

Penelitian selanjutnya diharapkan dapat menambah variabel penelitian dan memperluas sampel penelitian jumlah pesantren yang ada di wilayah Jawa yang bersedia untuk dijadikan objek penelitian sehingga hasil penelitian menjadi lebih akurat dan mencerminkan keadaan yang sebenarnya.

\section{Daftar Pustaka}

A. Ahunanya S, O Enyinna, M Abdullahi. 2010. Stakeholders Perception of Transparency and Accountability in Higher Education Financing In Lagos State. Lwati: A Journal of Contemporary Research. Vol 7 No 4.

B. Anggraini, Ristya Dwi. 2013. Transparansi, Partisipasi, dan Akuntabilitas Pengelolaan Anggaran Dana BOS Dalam Program RKAS di SDN Pacarkeling VIII Surabaya. Kebijakan dan Manajemen Publik. Volume 1, No 2. Hal. 201-208
C. Arifin, Zainal dan Ikhsan Budi Raharjo. 2013. Pertanggungjawaban Keuangan Pondok Pesantren: Studi pada Yayasan Nazhatut Thullab. Jurnal Ilmu \& Riset Akuntansi. Vol. 3. No.11.Hal.1-13

D. Azmy, Ahmad. 2015. Pengembangan Kompetensi Sumber Daya Manusia untuk Mencapai Career Ready Professional di Universitas Tanri Abeng. Binus Business Review. Vol. 6 No. 2. Hal. 220-232

E. Charlton, Donna dan William Allan Kritsonis. 2009-2010. Human Resource Management: Accountability, Reciprocity and the Nexus between Employer and Employee. National Forum of Educational Administration and Supervision Journal. Vol. 26. No. 3. Hal. 4661.

F. Delanno, Galuh Fajar dan Deviani. 2013. Pengaruh Kapasitas SDM, Pemanfaatan TI dan Pengawasan Keuangan Terhadap Nilai Informasi Pelaporan Keuangan Pemerintah Daerah. Jurnal WRA. Vol. 1. No. 1. Hal. 2146.

G. Febrianto, I Made Bagus, Gede Adi Yuniarta dan Edy Sujana. 2017. Analisis Faktor-Faktor yang Mempengaruhi Kualitas Akuntabilitas Keuangan Pada Satuan Kerja Perangkat Daerah (SKPD) Kabupaten Bangli. E-journal S1 Ak Universitas Pendidikan Ganesha. Volume 8. No.2. Hal 1-12.

H. Ghozali, Imam. 2014. Aplikasi Analisis Multivariate Dengan Program IBM SPSS 23. Semarang: Badan Penerbit Universitas Diponegoro.

I. Haris, Rillia Aisyah. 2014. Pengembangan Kapasitas Sumber Daya Manusia dalam Penyusunan Perencanaan Pembangunan Daerah (Suatu Kajian Pada Badan Perencanaan Pembangunan Daerah Kabupaten Sumenep). Jurnal Ilmiah Administrasi Publik. Vol.15 No.2. Hal. 1-12

J. Indriasari, Desi dan Ertambang Nahartyo. 2008. Pengaruh Kapasitas Sumber Daya Manusia, Pemanfaatan Teknologi Informasi, dan Pengendalian Intern Akuntansi terhadap Nilai Informasi Pelaporan Keuangan Pemerintah Daerah (Studi pada Pemerintah Kota Palembang Dan Kabupaten Ogan Ilir). SNA XI Pontianak

K. Murdayanti, Yunika, Suratno dan Suyanto. 2013. The Applicability of Good Governance to optimize The Public Service in Depok City. Eminence Scientific Journal of Management. Vol. 1 No. 1.Hal. 14-31

L. Murthy, Narasihma. 2012. Accountability of Any Personnel Manager. International Journal of Marketing and Technology. Vol. 2. No.9. Hal. 60-74.

M. Pratiwi, Ririh Dian dan Lilis Setyowati. 2017. Determinan Yang Mempengaruhi 
Akuntabilitas Kinerja Pemerintah Kota Semarang. Jurnal Bisnis dan Ekonomi (JBE). Volume. 24. No. 1. Hal. 94 - 102

N. Puruwita, Dita, Yunika Murdayanti, Darma Rika S dan Dewi Nurmalasari. 2015. Stakeholder Perception of Transparancey, Participation, and Accountability of School Financial Management. Paris Economics, Finance, and Business Proceedings. Paris: Perancis.

O. Rahmini Hadi. Parno. 2011. Manajemen Keuangan Konsep, Teori, dan Praktiknya di sekolah dan Pondok Pesantren. Purwokerto: STAIN Press.

P. Riantiarno, Reynaldi dan Nur Azlina. 2011. Faktor-Faktor Yang Mempengaruhi Akuntabilitas Kinerja Instansi Pemerintah (Studi pada Satuan Kerja Perangkat Daerah Kabupaten Rokan Hulu). Pekbis Jurnal. Vol.3, No.3. Hal. 560-568

Q. Robins, Stephen P dan Mary Coulter. 2016. Manajemen. Jilid 1 dan 2. Edisi 13. Jakarta: Erlangga.

R. Subkhan. 2012. Peranan Kyai Dalam Manajemen Pembiayaan Pendidikan Di Pondok Pesantren Asma' Chusna Kranji Kedungwuni Kabupaten Pekalongan. Journal of Economic Education. Vol. 1 Nomor 1. Hal. 79-83

S. Trakulmututa, Jutamanee dan Bussabong Chaijareonwattana. 2013. Good Governance in the Human Resource Management at the Level of Local Government: The Empirical Study of Southern Part of Thailand. International Journal of Business and Social Science. Vol. 2. No. 7. Hal. 46-53.

T. Usman, Idris Muhammad. 2013. Pesantren sebagai Lembaga Pendidikan Islam. Jurnal Al Hikmah. Vol. XIV no. 1.Hal. 101-119

U. Wijayanti, Ratna dan Nur Handayani. 2017. Pengaruh Kompetensi SDM dan Implementasi Akuntansi Akrual Terhadap Kualitas Laporan Keuangan Daerah. Jurnal Ilmu dan Riset Akuntansi. Vol. 6 No. 3. Hal.1290 - 1307.

V. Yakin, Nurul. 2014. Studi Kasus Pola Manajemen Pondok Pesantren Al-Raisiyah Di Kota Mataram.Ulumuna Jurnal Studi Keislaman, Vol. 18 Nomor 1. Hal.199-220

W. Zirman. Edfan Darlis dan R. Muhammad Rozi. 2010. Pengaruh Kompetensi Aparatur Pemerintah Daerah, Penerapan Akuntabilitas Keuangan, Motivasi Kerja, dan Ketaatan Pada Peraturan Perundangan Terhadap Akuntabilitas Kinerja Instansi Pemerintah. Jurnal Ekonomi. Vol. 8. Nomor. 1. Hal. 1-12. 